\title{
Gastric Cardia and Gastroesophageal Junction - An Ongoing Challenge for the Endoscopist and the Pathologist
}

\author{
Alfredo J. A. Barbosa and Rivelle D. Pereira \\ Additional information is available at the end of the chapter \\ http://dx.doi.org/10.5772/60554
}

\begin{abstract}
The cardiac mucosa of the human stomach is composed mainly of branched PAS positive mucous glands that occupy the deep half of the mucosa thickness. This morphological pattern of the mucous glands present in endoscopic biopsies from the gastric fundus region or near the gastroesophageal junction (GEJ) serves as parameter for the histological diagnosis of gastric cardia. However, this morphological pattern is highly variable along the gastric part of the GEJ: in some areas these mucous glands are abundant and in others they are scarce, if not totally absent. Depending on the concept adopted for some, the cardiac mucosa would be a native structure attached to human GEJ, while for others it would have a metaplastic origin that would occur during the extra-uterine life. In cardiac mucosa the mixed glands (mucous/oxyntic glands) are almost always present in between mucous glands and in between oxyntic glands; such as the parietal cells which could also be detected in greater or lesser amounts. The aim of this work was to evaluate the presence of serotonin-immunoreactive cells (EC cells) in these different types of glands in both normal cardiac mucosa as well as in the Barrett's esophagus. The main results concerning the endocrinology of gastric cardia allows to consider that the human cardia has exocrine and endocrine elements that together constitute its specific differential characteristic in relation to the gastric fundus and to the antropyloric regions of the stomach. On the other hand, the histologic and immunohistochemical analysis of endoscopic biopsies of 26 patients showed that $23(88.5 \%)$ of them presented varying amounts of mucous glands associated with intestinal metaplasia in distal esophagus. Moreover, many of these patients presented a rich component of serotoninergic EC cells. The major population
\end{abstract}


of serotonin-immunoreactive cells was found both in intestinal metaplasia as well as in its associated mucous glands. Among these patients, $16(70 \%)$ presented foci of high concentration of serotoninergic EC cell in the distal esophagus. Whatever the neuroendocrine actions of serotonin in the GEJ, these actions should be enhanced in many patients who present a large population of EC cells in gastric cardia as well as in the areas of intestinal metaplasia of those with Barrett's esophagus.

Keywords: Gastroesophageal junction, Cardiac mucosa, Endoscopy, Histology, Carditis, Barrett's esophagus, Endocrine cells, Neuroendocrine cells, APUD cells

\section{Introduction}

The gastric cardia is generally defined as the area of mucosa located distal to the anatomic gastroesophageal junction (GEJ) and proximal to the oxyntic mucosa of the gastric body. It is an area of the stomach that raises many controversies about its native glandular components. The gastric cardia mucosa is absent in the stomach of some mammals species, such as rat and guinea pig; in others, such as swine, it covers a large area of the stomach competing for space with the body's mucosa [1].In humans it is very limited in size. The gastric cardia mucosa cannot be evaluated by standard endoscopy, or even through direct visual examination of surgical specimens or when performing necropsies. However, it can often be detected by histological examination of tissues removed from the gastric mucosa close to the GEJ. In most individuals the edges of cardiac mucosa have an irregular shape and also it has a variable average length, usually $<2.0 \mathrm{~cm}$. Mucous glands morphologically similar to those of the antral mucosa are found in this region in varying amounts, usually predominating over other histological types of glands, namely, the mixed glands (mixed mucous/oxyntic glands) and the oxyntic glands. The latter are morphologically identical to the oxyntic glands in the body and can occupy large areas of cardiac mucosa, juxtaposed to the squamocolumnar junction.

The gastric cardia mucosa is histologically very similar to the mucosa of the antral region, i.e., the foveolas are long occupying about half of the mucosa thickness which are composed of branched mucous glands that occupy the deep half of the mucosa thickness. This morphological pattern of the mucous glands of tissues collected by the endoscopist from the gastric fundus region or near the GEJ serves as parameter for the histological diagnosis of gastric cardia. This histological criterion is used by a large number of pathologists. However, due to the highly variable distribution of mucous glands along the gastric part of the GEJ, in some areas they are abundant and in others they are scarce, if not totally absent. In short, in some areas the pure mucous glands may be missing altogether, and replaced by mixed gland and/or oxyntic glands. Typical oxyntic glands are easily recognized by histology lining the human gastric body and the gastric fundus. This type of mucosa can be easily recognized in histological sections due to the high density of compact glands, rich in acidophilus parietal cells, and basophil zymogen cells. In this case, the histology of endoscopic samples does not reveal the presence of typical mucous glands, which may cause erroneous endoscopic-histologic 
correlation. Because of the gastric cardia irregularity, divergent hypothesis arises on its real constitution and on its real presence in all subjects [2-5].

The cardiac mucosa also has a component of endocrine cells with unknown functions. This gap in knowledge about the importance of the endocrine population of the gastric cardia may be due to its conceptual status not yet well defined. In addition, the occurrence of local pathological processes of the GEJ modifies its structure hindering its proper identification. Among these processes the reflux esophagitis, the $\mathrm{H}$. pylori infection, and the occurrence of intestinal metaplasia [6-8] should be mentioned.

\section{Aims}

Numerous endocrine cells stained with antibodies anti-chromogranin was found in gastric cardia in patients with endoscopically normal GEJ. This bunch of endocrine cells was found to be formed by a single population of serotonin-producing EC cells [9]. In gastrointestinal mucosa the serotonin-producing cells are also called "enterochromafin cells" (abbreviated: EC cells). It was then proposed that the EC cells were the only representatives of the rich gastric endocrine component of the gastric cardia. In the present work we studied standard endoscopic biopsies from the GEJ region aimed to assess the presence of different types of glands which occur in the gastric cardia and its component of serotoninergic EC cells. We also evaluated in a series of patients with Barrett's esophagus the different types of glands seen in the distal tubular esophagus and its content of serotonin-producing EC cells.

\section{Material and methods}

\subsection{Histology and EC cells in gastric cardia}

Endoscopic biopsies of two groups of consecutive patients attended at the Instituto Alfa de Gastroenterologia (IAG), Hospital das Clinicas, Universidade Federal de Minas Gerais (UFMG), Belo Horizonte, Brazil were studied. Group 1: made up of 21 patients who underwent upper gastrointestinal endoscopy in whom no significant changes of the esophagus and stomach were found. From these patients at least 2 biopsies containing cardiac mucosa were obtained from the area of the GEJ, and also 2 biopsies were obtained from each, antral and body mucosa of the stomach. Group 2: made up of 26 patients with endoscopic diagnosis of Barrett's esophagus $(>3 \mathrm{~cm}$ ) in which at least 2 biopsies were performed for the diagnosis confirmation.

Sections of tissue were stained with Hematoxylin and Eosin (HE), Giemsa and PAS / Alcian Blue for histology. Ancillary stains used for cardiac mucosa analysis were: (1) immunohistochemical staining for demonstration of serotonin-producing EC cells using a primary monoclonal antibodies against serotonin (Dako A / S, Denmark), and (2) Grimelius staining for demonstration argyrophil cells [10]. Because of the irregularity of the gastric cardia 
tissue specimens, the EC cells and argyrophil cells were quantified in glandular tissues where they presented the highest concentration (hot spot). In order to quantify the hot spot cell number, the high-power microscopic field was used and, thus, the number of cells/hpf was obtained. According to this criterion, the cell number was classified as few $(<10 / \mathrm{hpf})$ or numerous ( $\geq 10 / \mathrm{hpf})$.

The presence of parietal cells in cardiac mucosa was evaluated in slides stained with HE. With this routine staining method these cells are easily recognizable, particularly in areas where they were numerous. In cases where they were not evident in HE preparations, or apparently very scarce, ancillary immunohistochemical stainingwas carried out using primary monoclonal antibodies against secretory canaliculi antigen of parietal cell (Barbosa, A.J.A., personal information).

\subsection{EC cells in Barrett's esophagus}

Twenty six patients (mean age 36 years, range 22-69 years) with Barrett's esophagus in whom at least 2 biopsies were performed for diagnostic confirmation were studied. All of them presented salmon-colored columnar mucosa extending in tongue-shaped projections at least $3 \mathrm{~cm}$ above the GEJ. The cases associated with gastrointestinal cancer and high-grade dysplasia of the columnar epithelium were excluded. Histological sections were reviewed to confirm the diagnosis and assessment of tissue structures present, namely, squamocolumnar junction, typical mucous glands, intestinal metaplasia with goblet cells, and the presence of hot spots of serotonin-immunoreactive EC cells. The quantitative evaluation of EC cells followed the same criterion as for the gastric cardia, i.e., few cells ( $<10 \mathrm{hpf})$ or numerous cells $(\geq 10 / \mathrm{hpf})$.

\section{Results}

\subsection{Gastric cardia}

Most of the 21 patients (mean age 36 years; range 22-69 years; 14 female) underwent endoscopy looking for obscure causes of anemia, obscure GI bleeding, or as a preoperative control. H. pylori was negative in 11 (52.4\%) patients, both in cardiac mucosa and in the gastric body and antrum. Among these 11 patients 3 had the diagnosis of atrophic body gastritis (ABG). The histology results of the 8 remaining $\mathrm{H}$. pylori-negative patients showed gastric mucosa of the antrum and body histologically normal and mononuclear inflammatory infiltration in cardiac mucosa. This inflammatory infiltrate was mild in 3 patients (mild carditis) and moderate in 5 patients (moderate carditis). Parietal cells were absent in cardiac mucosa of $4 \mathrm{H}$. pylori negative patients, 3 of them with ABG. In one patient, a small number of glands with goblet cells was found, indicating the presence of intestinal metaplasia (Table 1).

H. pylori infection occurred in $10(47.6 \%)$ patients, and in 5 of these patients this microorganism was demonstrated in cardiac mucosa. The results of histology showed the presence of gastritis with mild inflammatory activity $(+)$ or moderate $(++)$ in the gastric mucosa of the antrum and body, with greater intensity in the antral mucosa. All patients in this subgroup had carditis of 


\begin{tabular}{cccccc}
\hline $\begin{array}{c}\text { Patient } \\
\text { number }\end{array}$ & $\begin{array}{c}\text { Antrum/Corpus } \\
(\mathrm{HE})\end{array}$ & $\begin{array}{c}\text { Cardia } \\
(\mathrm{HE})\end{array}$ & $\begin{array}{c}\text { Cardia } \\
(\text { H. } \text { pylori })\end{array}$ & $\begin{array}{c}\text { Antrum/Corpus } \\
(\text { H. } \text { pylori })\end{array}$ & $\begin{array}{c}\text { Cardia } \\
\text { Mucous glands/ PC }\end{array}$ \\
\hline 2 & $\mathrm{~N}$ & + & - & - & PAS+ / PC+ \\
\hline 3 & $\mathrm{~N}$ & + & - & - & PAS+ / PC+ \\
\hline 8 & $\mathrm{~N}$ & ++ & - & - & PAS+ / PC+ \\
\hline 13 & $\mathrm{~N}$ & + & - & - & PAS+ / PC+ \\
\hline 18 & $\mathrm{~N}$ & ++ & - & PAS+/PC+ + PC+ \\
\hline 19 & $\mathrm{~N}$ & ++ & - & PAS+ / PC+ \\
\hline 20 & $\mathrm{~N}$ & ++ & - & - & PAS+ / PC+ \\
\hline
\end{tabular}

$\mathrm{N}=$ Normal histology; $+/++=$ mild/moderate degree of inflammatory cells in lamina propria; PAS $+=$ Mucous glands present; IM+ = Intestinal metaplasia present; PC+ = Parietal cell present.

Table 1. Histology of the gastric mucosa of the antrum, corpus, and cardia of the 8 H. pylori negative patients. The $3 H$. pylori negative patients with ABG were not included in this table.

moderate intensity, regardless of the presence of $\mathrm{H}$. pylori. Typical parietal cells were present in the cardiac mucosa samples in varying amounts. In two patients PAS / AB staining revealed the presence of intestinal metaplasia foci in cardiac mucosa (Table 2).

\begin{tabular}{|c|c|c|c|c|c|}
\hline $\begin{array}{l}\text { Patient } \\
\text { number }\end{array}$ & $\begin{array}{c}\text { Antrum/Corpus } \\
(H E)\end{array}$ & $\begin{array}{c}\text { Cardia } \\
(H E)\end{array}$ & $\begin{array}{c}\text { Cardia } \\
\text { (H.pylori) }\end{array}$ & $\begin{array}{c}\text { Antrum/Corpus } \\
\text { (H. pylori) }\end{array}$ & $\begin{array}{c}\text { Cardia } \\
\text { Mucous glands/ PC }\end{array}$ \\
\hline 1 & $++/+$ & ++ & + & + & $\mathrm{PAS}+/ \mathrm{PC}+$ \\
\hline 4 & $++/+$ & ++ & + & + & PAS+ / PC + \\
\hline 5 & $++/+$ & + & + & + & PAS+ / PC + \\
\hline 6 & $++/+$ & ++ & - & + & $\mathrm{PAS}+/ \mathrm{CP}+$ \\
\hline 9 & $++/++$ & ++ & - & + & PAS+IM+/PC+ \\
\hline 10 & $+/++$ & ++ & - & + & $\mathrm{PAS}+/ \mathrm{PC}+$ \\
\hline 11 & $++/++$ & ++ & - & + & $\mathrm{PAS}+/ \mathrm{PC}+$ \\
\hline 14 & $+1++$ & ++ & - & + & PAS+ / PC - \\
\hline 15 & $++/+$ & ++ & + & + & $\mathrm{PAS}+$ / PC + \\
\hline 21 & $++/++$ & ++ & + & + & $\mathrm{PAS}+\mathrm{IM}+/ \mathrm{PC}+$ \\
\hline
\end{tabular}

+/++ =Mild/Moderate degree of inflammatory cells; PAS+ = Mucous glands present; IM+ = Intestinal metaplasia present; PC $+=$ Parietal cell present; PC $-=$ Parietal cell absent.

Table 2. Histology of the gastric mucosa of the antrum, corpus, and cardia of the $10 \mathrm{H}$. pylori positive patients. 


\subsection{H. pylori, gastritis, and carditis}

Inflammatory infiltrate of mononuclear cells and neutrophils (PMNs) were present in the gastric antrum and gastric body in all $\mathrm{H}$. pylori positive patients and in the 3 patients with atrophic body gastritis. Mild or moderate chronic carditis was seen in all patients, regardless of the presence of the bacterium H. pylori (Table 2, Figure 1).

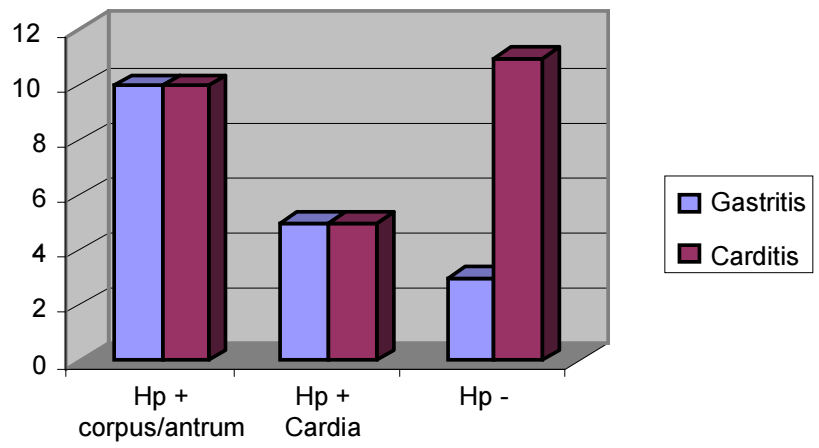

Figure 1. Presence of gastritis and carditis in H. pylori positive and H. pylori negative patients. The only three patients who were H. pylori negative with gastritis had ABG (type A gastritis).

\subsection{Argyrophil and EC cells in gastric cardia}

In $2(9.5 \%)$ patients, argyrophil or serotonergic cells were not detected in the samples of cardiac mucosa. The number of patients with few argyrophil and EC cells $(<10 / \mathrm{hpf})$ were similar, respectively, $38.1 \%$ vs $42.8 \%$. Moreover, the number of patients presenting hot spots with numerous argyrophil and EC cells ( $\geq 10$ / hpf) was also similar, respectively, $52.4 \%$ vs $47.6 \%$ (Figures 2 and 3).

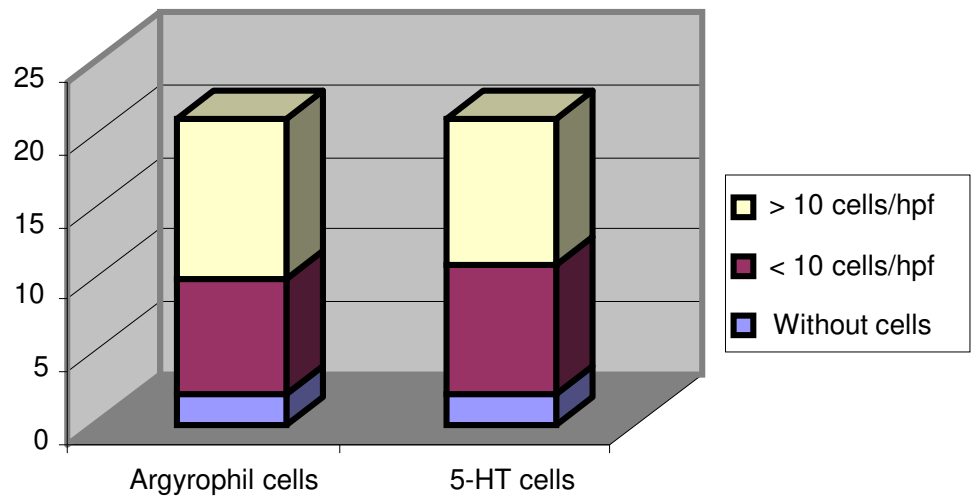

Figure 2. Quantitative relationship of argyrophil and 5HT- cells (EC cells) in cardiac mucosa of the 21 patients studied. 


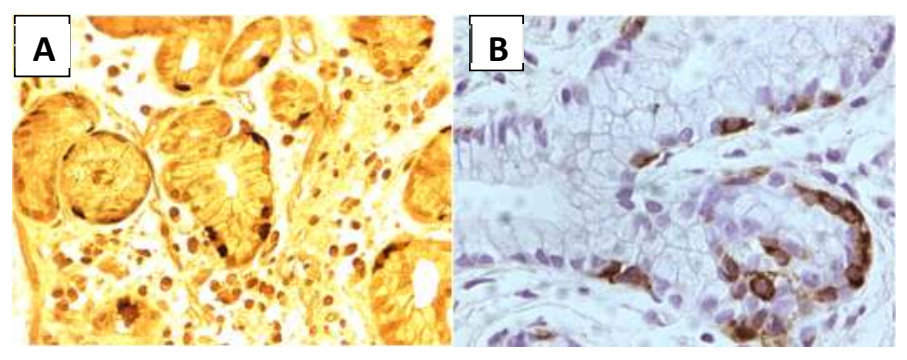

Figure 3. High-power photograph of the argyrophil (A) and serotoninergic (B) cells in mucous glands of the gastric cardia mucosa of patients with no endoscopic changes in the upper digestive tract.

\subsection{Parietal cells in cardiac mucosa}

The presence of parietal cells in histological sections of the cardiac mucosa was observed in 17 patients. Among them, 10 patients (47.6\%) presented parietal cells relatively numerous and easily identifiable by routine staining; however, in 7 (33.3\%) the parietal cells could only be identified with certainty by immunohistochemical staining. In $4(19.1 \%)$ patients parietal cells were negative by routine staining and immunohistochemistry. Among them 3 had the diagnosis of atrophic body gastritis (Tables 1 and 2, Figure 4).

\subsection{Barrett's esophagus}

In all 26 patients with Barrett's esophagus the presence of intestinal metaplasia with goblet cell was confirmed. In $23(88.5 \%)$ of them, cardiac type mucous glands were present in tissue sections associated with intestinal metaplasia. In 2 of these patients no detectable EC cells were found in these glands. It should be considered that in most of the patients with Barrett's esophagus the areas of intestinal metaplasia were significantly more extensive than the areas occupied by mucous glands. Oxyntic glands were not observed in Barrett's esophagus samples. The major EC cell concentrations were found both in areas of intestinal metaplasia and in areas occupied by mucous glands. In the 23 patients with mucous glands in the histological sections the foci of high concentrations of EC cells ( $\geq 10$ / hpf) occurred in $16(70 \%)$ of them. Similar frequency of high concentrations of serotonergic cells was observed in the areas of intestinal metaplasia: among the 26 patients studied $15(58 \%)$ presented with numerous EC cells foci in metaplastic glands (Table 3, Figure 5).

\begin{tabular}{lll}
\hline Type of glands & $\mathbf{n}<10 \mathrm{EC}$ cells/hpf & $\geq 10 \mathrm{EC}$ cells/hpf \\
\hline Mucous $(21 / 23)$ & $05(24 \%)$ & $16(76 \%)$ \\
\hline IM $(26 / 26)$ & $11(42 \%)$ & $15(58 \%)$ \\
\hline
\end{tabular}

$\mathrm{IM}=$ Intestinal metaplasia

Table 3. Type of glands present in the columnar mucosa of 26 patients with Barrett's esophagus, and their concentration of few ( $<10 \mathrm{EC}$ cells/hpf) or numerous ( $\geq 10 \mathrm{EC}$ cells/hpf) serotonin-immunoreactive cells. 


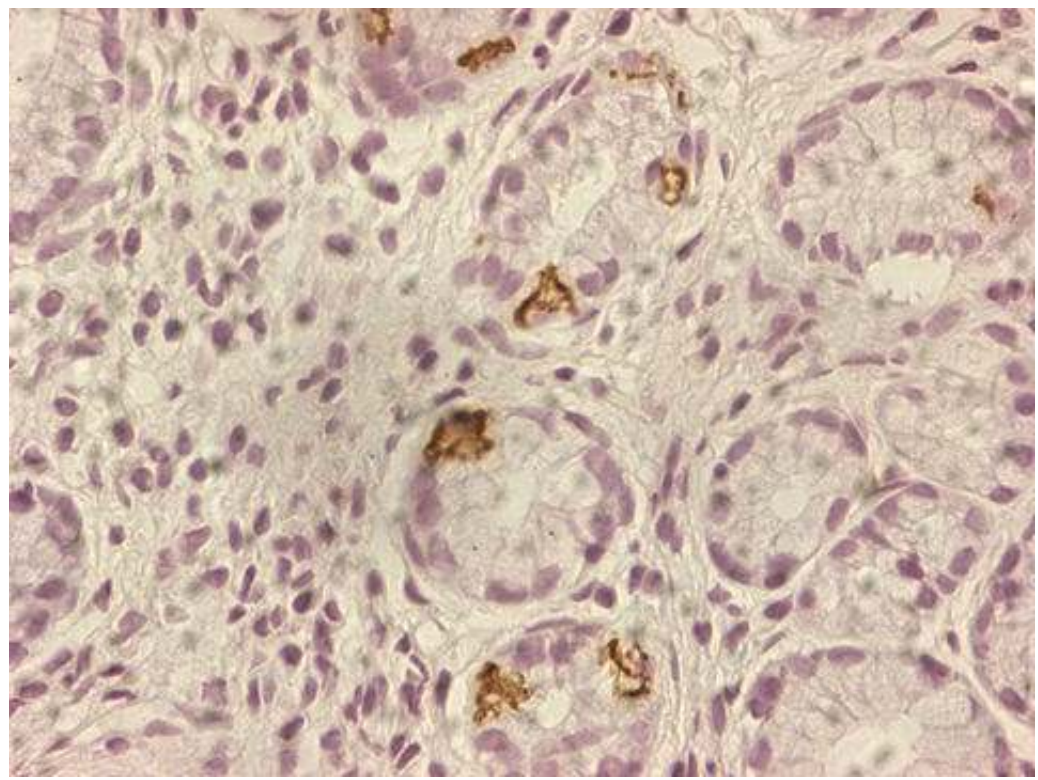

Figure 4. High-power photograph of gastric cardia mucosa composed mainly by mucous glands as a background of immunohistochemical staining. In between the mucinous cells there are few unexpected parietal cells with their secretory canaliculi stained in brown. A mild degree of mononuclear inflammatory cells is present in lamina propria.

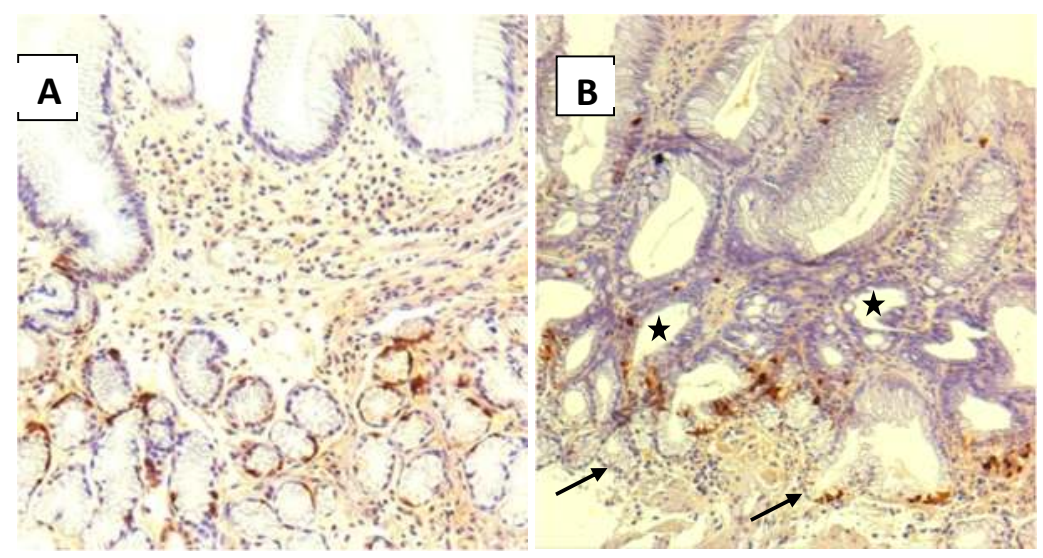

Figure 5. (A) Gastric cardia composed of mucinous columnar epithelium with underlying mucous glands that exhibit numerous serotonin-immunoreactive EC cells stained in brown. A mild degree of inflammatory mononuclear cells in lamina propria is present which seems to be a normal component of the gastric cardia in most individuals. (B) Barrett's esophagus presenting the mucosa composed of mucinous columnar epithelium (upper side) with underlying glands presenting intestinal metaplasia (stars), and mucous glands in the bottom (arrows) of the photograph. Presence of serotonin-immunoreactive EC cells in both type of glands. 


\section{Discussion}

Outside the limits of the standard endoscopy the mucosa of the gastric cardia remains an issue of much controversy due to its variable glandular constitution and its imprecise limits. Because there is no established knowledge about its functions this region of the stomach is usually relegated to the background when studying the physiology and pathophysiology of gastric mucosa. Usually cardiac mucosa is histologically defined as consisting of mucous glands which occupy the most proximal area of the gastric mucosa. It has a variable length, occupying an irregular band of approximately $0.5-2 \mathrm{~cm}$ in most individuals.

Many of the controversies in the literature about the status of the gastric cardia derive from concepts still poorly defined of its nature. Those who consider it to be a specific type of gastric mucosa characterized by the presence of well-defined lobes of PAS-positive mucous glands believe that the cardiac mucosa would occur only in a certain number of individuals, increasing its presence and extent progressively with age. Depending on the concept adopted, for some the cardiac mucosa would be a native structure attached to human GEJ, while for others it would have metaplastic origin that occurs during the extra-uterine life $[2,3]$.

Another question not always easy to answer is the definition of the GEJ. Often the endoscopist sets the GEJ as the transition area between squamous mucosa ends and the level of the rise of visible gastric folds. That is, in most individuals the GEJ can be endoscopically defined as the most proximal area of the stomach folds which represents the transition point between the squamous epithelium of the esophagus and the columnar mucus-secreting epithelium of the stomach, called $\mathrm{Z}$ line. However, this endoscopic criterion may be flawed due to frequent pathological changes that occur in this area. In these cases the $\mathrm{Z}$ line may move proximally and consequently taking anatomical position above GEJ [11].

We do not intend to discuss here the anatomical limits of the cardiac mucosa. At this point it would be better to forget the anatomical limits of the cardia and to turn our gaze to its morphological components. On the other hand, we should seek to learn about its seemingly exclusive endocrine component, made up of EC cells, a fact that is not usually taken into account in the conceptual controversies on this specific type of gastric mucosa. In general cardiac mucosa is understood as located in the most proximal region of the gastric mucosa, and presenting PAS-positive mucous glands and mixed glands whether or not accompanied by oxyntic glands. However, this concept only becomes complete after setting its endocrine pattern, characterized by a striking or exclusive presence of the population of EC cells. Once conceptualized thereby the cardiac mucosa would acquire its own characteristics making it distinct from the antropyloric and corpus mucosa of the stomach. Moreover, the gastric cardia also could acquire a greater degree of independence from endoscopic reports, since it would become possible to fit both its location in the stomach as in a heterotopic location of the distal esophagus, with or without the Barrett's epithelium.

\subsection{H. pylori and gastric cardia}

It is well known that the standard endoscopy of the gastric mucosa does not relate well with the histological findings of $\mathrm{H}$. pylori-associated gastritis of the antrum and corpus. The same 
seems to happen with the cardiac mucosa in the absence of ulcerative lesions. In this series of 21 patients with endoscopically normal gastroesophageal mucosa, 10 (47.6\%) had H. pylori infection and chronic gastritis of the antrum and corpus, and in 5 of these patients $(50 \%)$ the bacteria were also identified in cardiac mucosa. However, all 10 patients had chronic carditis (Table 2). Chronic carditis with similar intensity was also observed in the 8 patients $(38.1 \%)$ who were H. pylori-negative (Table 1).

The presence of $\mathrm{H}$. pylori only in cardiac mucosa is not common. In nearly all cases if it is found in gastric cardia it should also be found in the gastric body or in antral regions. Therefore, all cases of $\mathrm{H}$. pylori-positive chronic carditis will occur always with $\mathrm{H}$. pylori-associated chronic gastritis [12]. On the other hand, regardless the presence of the bacteria, the carditis we found here had similar intensity in all 10 patients, $\mathrm{H}$. pylori negative or positive. It is known that the main cause of inflammatory reaction of the gastric antrum and corpus is the H. pylori infection. In turn, the nonspecific inflammatory processes occurring in cardiac mucosa are frequently said to be a consequence of gastroesophageal reflux disease occurring in subclinical conditions, as appears to be the case of the present series of patients.

\subsection{Parietal cells and gastric cardia}

Atrophic body gastritis (ABG) occurred in 3 (14.3\%) patients of the present series. The corpus glandular atrophy was due to the total depletion of oxyntic glands in the tissue samples that were examined. It should be noted that while this atrophy has been intense and easily identified by histology, it was unnoticed by standard endoscopy. This discrepant result, apparently surprising, is not at all uncommon in reports from hospital units of standard gastrointestinal endoscopy. ABG can also go undetected by routine histopathological examination, as a consequence of the morphological disruption getting the atrophic body's mucosa [13]. Most of the cases of ABG would have an autoimmune background, and thus it could explain the absence of parietal cells in the gastric cardia of the 3 patients with ABG, even using immunohistochemistry for the identification of these cells.

With the exception of the 3 patients with ABG only one patient among the other 18 subjects had no parietal cells in gastric cardia, which could be a sampling bias. This result shows that oxyntic glands with typical parietal cells easily demonstrated by HE staining are commonly found interposed between mucous and mixed glands. We think that this morphologic pattern is a common finding near to GEJ and could be considered as a normal structure of the human cardiac mucosa. In some cases, as seen in the present study, the parietal cells were apparently absent at the HE examination; nevertheless they could be identified by immunohistochemical staining (Figure 4). In areas of the GEJ where parietal cells are abundant, frequently juxtaposed to the squamocolumnar junction, the examiner may have the false impression about possible absence of cardiac mucosa [14].

In cardiac mucosa the mixed glands are almost always present in between mucous glands and in between oxyntic glands; such as the parietal cells which could also be detected in greater or lesser amounts [7]. Thus, the concept of human cardiac mucosa should cover this large range of different types of glands and in different proportions. 


\subsection{Endocrine component of the gastric cardia}

The population of endocrine cells of the human cardiac mucosa is almost entirely, if not all, constituted by serotonin producing EC cells. EC cells have high affinity for silver salts, which is frequently employed to stain these cells. Two general silver methods may be used for this purpose, the argentaffin (Fontana-Masson method) and the argyrophilic stains. Among the latter the Grimelius method seems to be the most widely used.

At this point we should remember that: (a) the EC cells are argentaffin cells and can be easily stained in ammoniacal silver nitrate solution and this method can be applied to reveal gastrointestinal EC cells from different animal species [15]; (b) EC cells, as being argentaffin, can also be stained by the Grimelius indirect argyrophilic method; (c) the EC cells could not only produce serotonin; there are subsets of these cells that express, in addition to serotonin, different peptidergic hormones [16-18]; (d) finally it should be remembered that there are numerous different types of neuroendocrine cells which produce different peptides and having the same argyrophilic properties described above. In fact, almost all the neuroendocrine cells of the digestive tract of man can be easily demonstrated by Grimelius staining method. In the present study, we found that the population of serotonin-producing EC cells in gastric cardia, specifically demonstrated by immunohistochemistry, was roughly equivalent to the population of argyrophil cells.

Our results concerning the endocrinology of gastric cardia, along with those previously published by others, allow to consider that the human cardia, although occupying a restricted area of the stomach, has exocrine and endocrine elements that together constitute its differential characteristic (maybe specific) in relation to the gastric fundus and the antropyloric regions. Briefly, it could be said that in the antral mucosa the EC cells divide the space mainly with the G cells (gastrin) and D cells (somatostatin). In turn, in the body region of the human stomach EC cells are rare or absent, giving space mainly for the enterochromaffin-like (ECL) cells, the most numerous in this region. Finally, in the gastric cardia the EC cells are numerous and constitute the sole or predominant cell type (Figure 6).

Therefore, considering all the exocrine and endocrine elements of the human gastric cardia, many controversies reported in the literature on its morphological characteristics and also about its definition seem to be half-finished. Usually these discussions are mainly based on arguments related to its histologically most characteristic exocrine component, i.e., the presence of PAS-positive mucous glands [3]. At this point it could be summarized regarding the anatomy of the human gastric cardia mucosa: [i] a wide variation of different types of exocrine glands and [ii] the presence of a large number of serotoninergic EC cells in mucous glands and in mucous/oxyntic glands (mixed glands).

Serotonin (5-HT) seems to present important neuroendocrine functions in different segments of the gastrointestinal tract, including the control of gastrointestinal motility. Serotonin functions are mediated via specific receptors [19-21]. Some of these receptors have been described recently in the lower esophageal sphincter (LES) and the authors speculate on the role of serotonin in the modulation of its activity [22]. The 5HT1 and 5HT7 receptors are considered to be muscle relaxation promoters while 5HT2, 5HT3, and 5HT4 to be stimulating 


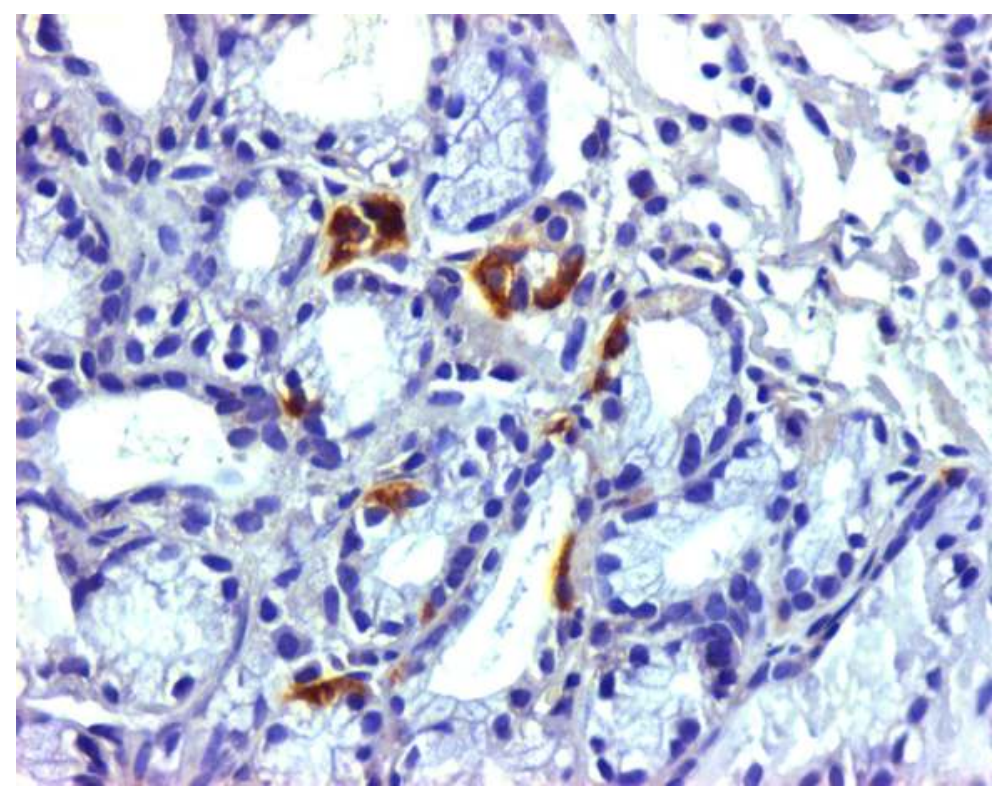

Figure 6. High-power microscopic field shows a marked number (> 10 cells/hpf) of serotonin-immunoreactive EC cells in mucous glands of the gastric cardia. The EC cells appear to be the only (or largely predominanting) population of endocrine cells in this region of the human stomach. This fact seems to be characteristic of these mucous glands, and as such it should be included in the morphological definition of the human gastric cardia.

muscle contraction [23-25]. Therefore, the frequent and relatively abundant presence of serotonergic cells in the human gastric cardia, next to GEJ, could act as a modulating factor of the neuromuscular activity of the LES. The disruption of LES functional activity is considered nowadays as the main cause of the gastroesophageal reflux disease, frequent pathological condition in the general population, and the main cause of reflux esophagitis and Barrett's esophagus.

\subsection{Serotoninergic cells and Barrett's esophagus}

The diagnosis of Barrett's esophagus requires endoscopic evidence showing columnar mucosa above the GEJ, lining the distal esophagus, and this change must be confirmed by histopathological analysis. Thus, the result of histology should confirm the presence of columnar epithelium emphasizing the presence of goblet cells. Endoscopicaly the GEJ is identified as being the most proximal area to the start of gastric folds. Therefore, projections shaped like red salmon-color tongues above this area, lining the distal esophagus, are interpreted by the endoscopist as Barrett's esophagus. Macroscopically, these red-salmon tongues are often quite irregular in their proximal limits, and the microscopic foci of intestinal metaplasia, with or without goblet cells, can also have an irregular distribution.

Therefore, when biopsies are done near the limits of salmon-red areas the histopathological results can reveal the squamocolumnar junction in the absence of intestinal metaplasia. That 
is, the histological examination may notice the presence of columnar mucosa composed mainly by glands lined by mucous-secreting epithelium with or without brush border, and with mucous cardiac-like glands, however, without the presence of goblet cells. In general, the North American gastroenterology societies require the presence of goblet cells to confirm the intestinal metaplasia and, consequently, the diagnosis of Barrett's esophagus; differently, the British societies admit that the presence of columnar epithelium lining the esophagus with cardiac type mucous glands can be accepted as a criterion for the definitive diagnosis of Barrett's esophagus [26, 27].

Regardless of this conceptual controversy on the definition of Barrett's esophagus it should be stressed the presence of the abundant serotoninergic cells in the intestinal-, and cardiactype glands that cover the inner wall of the tubular esophagus. These groups of cardiac-type glands are found frequently in endoscopic biopsies of Barrett's esophagus and seem to have preserved their rich component of serotonergic cells. The analysis of the present series of biopsy fragments showed that among patients with Barrett's esophagus, 23 (88.5\%) of them showed varying amounts of mucous glands associated with intestinal metaplasia; among these patients, 16 (70\%) had foci with high concentration of serotoninergic EC cells.

Therefore, it seems to happen in Barrett's esophagus a fertile soil for serotonergic cells proliferation since they can replicate themselves both in the cardiac-like epithelium as in the intestinal metaplastic glands. Mucous glands present in the tubular esophagus and associated with intestinal metaplasia do not have a well-explained histogenesis. Whether metaplastic or not, they are mirror images of its sisters present in the normal gastric cardia, even as a depository of serotonergic cells. Whatever the neuroendocrine actions of serotonin in the lower esophagus, these actions should be enhanced in large number of patients with Barrett's esophagus, because of the simultaneous presence in these patients of the extra population of serotoninergic cells present in the areas of intestinal metaplasia.

We have seen that in the normal gastric cardia the population of argyrophil cells is represented almost entirely by the serotoninergic EC cells. However, in the areas of Barrett's intestinal metaplasia the population of argyrophil cells should be a more diverse bunch of endocrine cells since the intestinal mucosa is a rich depository of different types of these cells. Indeed, immunohistochemical studies of Barrett's esophagus demonstrated not only the significant presence of EC cells as well as varying numbers of immunoreactive cells to somatostatin, motilin, pancreatic peptide, gastrin, glucagon, secretin, and neurotensin. These findings led the authors to propose that Barrett's epithelium would be derived from multipotent stem cells with ability to differentiate into gastric and intestinal epithelium [28, 29].

Although 30 years have passed after the first suspicions by Buchan, Rindi, and colleagues about the multipotent stem cells as an explanation for the histogenesis of Barrett's epithelium, it still remains in the territory of speculations. Nowadays various hypothesis of multipotential stem cells are still in focus. It is proposed that these stem cells would be derived from the bone marrow, or from the basal layer of the squamous epithelium or from the mucous gland ducts located in the submucosa of the esophagus. Other possibility would be the possible remaining of embryonic tissues in the area of GEJ. Similar issues occur nowadays regarding the histo- 
genesis of the epithelium of the human gastric cardia. From what we see, here too we have no definitive answers.

\section{Acknowledgements}

This work was supported by grants from the Conselho Nacional de Desenvolvimento Científico e Tecnológico (CNPq), Distrito Federal, Brasil, and by Fundação de Amparo à Pesquisa do Estado de Minas Gerais (FAPEMIG), Belo Horizonte, Brasil.The authors thank Ms. Luciene S. P. Faria, from the IAG Laboratory of Gastrointestinal Histopathology, for technical assistance.

\section{Author details}

Alfredo J. A. Barbosa ${ }^{1,2^{*}}$ and Rivelle D. Pereira ${ }^{1}$

*Address all correspondence to: abarbosa@medicina.ufmg.br

1 Laboratory of Digestive and Neuroendocrine Pathology, UFMG, Belo Horizonte, Brazil

2 Faculdade de Medicina, Universidade Federal de Minas Gerais (UFMG), and Instituto Alfa de Gastroenterologia do Hospital das Clínicas, UFMG, Belo Horizonte, Brazil

\section{References}

[1] Barbosa AJA, Silva JC, Nogueira AMMF, Paulino Junior E, Miranda CR. Higher incidence of Gastrospirillum sp. in swine with gastric ulcer of the pars oesophagea. Veterinary pathology. 1995 Mar;32(2):134-9. PubMed PMID: 7771053.

[2] Chandrasoma PT, Der R, Ma Y, Dalton P, Taira M. Histology of the gastroesophageal junction: an autopsy study. The American journal of surgical pathology. 2000 Mar; 24(3):402-9. PubMed PMID: 10716154.

[3] Kilgore SP, Ormsby AH, Gramlich TL, Rice TW, Richter JE, Falk GW, et al. The gastric cardia: fact or fiction? The American journal of gastroenterology. 2000 Apr;95(4): 921-4. PubMed PMID: 10763938.

[4] Zhou H, Greco MA, Daum F, Kahn E. Origin of cardiac mucosa: ontogenic consideration. Pediatric and developmental pathology : the official journal of the Society for Pediatric Pathology and the Paediatric Pathology Society. 2001 Jul-Aug;4(4):358-63. PubMed PMID: 11441337. 
[5] Glickman JN, Chen YY, Wang HH, Antonioli DA, Odze RD. Phenotypic characteristics of a distinctive multilayered epithelium suggests that it is a precursor in the development of Barrett's esophagus. The American journal of surgical pathology. 2001 May;25(5):569-78. PubMed PMID: 11342767.

[6] Malfertheiner P, Peitz U. The interplay between Helicobacter pylori, gastro-oesophageal reflux disease, and intestinal metaplasia. Gut. 2005 Mar;54 Suppl 1:i13-20. PubMed PMID: 15711003. Pubmed Central PMCID: 1867793.

[7] Odze RD. Pathology of the gastroesophageal junction. Seminars in diagnostic pathology. 2005 Nov;22(4):256-65. PubMed PMID: 16939053.

[8] Ringhofer C, Lenglinger J, Izay B, Kolarik K, Zacherl J, Eisler M, et al. Histopathology of the endoscopic esophagogastric junction in patients with gastroesophageal reflux disease. Wiener klinische Wochenschrift. 2008;120(11-12):350-9. PubMed PMID: 18709523.

[9] Voutilainen M, Juhola M, Pitkanen R, Farkkila M, Sipponen P. Immunohistochemical study of neuroendocrine cells at the gastric cardia mucosa. Journal of clinical pathology. 2002 Oct;55(10):767-9. PubMed PMID: WOS:000178513100011. English.

[10] Grimelius L, Wilander E. Silver stains in the study of endocrine cells of the gut and pancreas. Investigative \& cell pathology. 1980 Jan-Mar;3(1):3-12. PubMed PMID: 6156147.

[11] Sharma P, Morales TG, Sampliner RE. Short segment Barrett's esophagus--the need for standardization of the definition and of endoscopic criteria. The American journal of gastroenterology. 1998 Jul;93(7):1033-6. PubMed PMID: 9672325.

[12] Genta RM, Huberman RM, Graham DY. The gastric cardia in Helicobacter pylori infection. Human pathology. 1994 Sep;25(9):915-9. PubMed PMID: 8088767.

[13] Barbosa AJA, Miranda CG Atrophic body gastritis: A challenge for the presumptive endoscopic and histologic diagnosis of autoimmune gastritis. In: Pascu O, editor. Gastrointestinal endoscopy. Rijeka, Croatia: InTech; 2011. p. 169-82.

[14] Sarbia M, Donner A, Gabbert HE. Histopathology of the gastroesophageal junction: a study on 36 operation specimens. The American journal of surgical pathology. 2002 Sep;26(9):1207-12. PubMed PMID: 12218577.

[15] Barbosa AJA, Castro LPF,, Nogueira AMMF. A simple and economical modification of the Masson-Fontana method for staining melanin granules and enterochromaffin cells. Stain technology. 1984 Jul;59(4):193-6. PubMed PMID: 6208641.

[16] Pearse AG, Polak JM. Immunocytochemical localization of substance P in mammalian intestine. Histochemistry. 1975;41(4):373-5. PubMed PMID: 1095530. 
[17] Alumets J, Hakanson R, Sundler F, Chang KJ. Leu-enkephalin-like material in nerves and enterochromaffin cells in the gut. An immunohistochemical study. Histochemistry. 1978 Jul 12;56(3-4):187-96. PubMed PMID: 99394.

[18] Heitz PU, Kasper M, Krey G, Polak JM, Pearse AG. Immunoelectron cytochemical localization of motilin in human duodenal enterochromaffin cells. Gastroenterology. 1978 Apr;74(4):713-7. PubMed PMID: 344128.

[19] Hempfling C, Neuhuber WL, Worl J. Serotonin-immunoreactive neurons and mast cells in the mouse esophagus suggest involvement of serotonin in both motility control and neuroimmune interactions. Neurogastroenterology and motility : the official journal of the European Gastrointestinal Motility Society. 2012 Jan;24(1):e67-78. PubMed PMID: 22029710.

[20] Li Z, Chalazonitis A, Huang YY, Mann JJ, Margolis KG, Yang QM, et al. Essential roles of enteric neuronal serotonin in gastrointestinal motility and the development/ survival of enteric dopaminergic neurons. The Journal of neuroscience : the official journal of the society for neuroscience. 2011 Jun 15;31(24):8998-9009. PubMed PMID: 21677183.

[21] Kapeller J, Moller D, Lasitschka F, Autschbach F, Hovius R, Rappold G, et al. Serotonin receptor diversity in the human colon: Expression of serotonin type 3 receptor subunits 5-HT3C, 5-HT3D, and 5-HT3E. The journal of comparative neurology. 2011 Feb 15;519(3):420-32. PubMed PMID: 21192076. Pubmed Central PMCID: 3056486.

[22] Li HF, Liu JF, Zhang K, Feng Y. Expression of serotonin receptors in human lower esophageal sphincter. Experimental and therapeutic medicine. 2015 Jan;9(1):49-54. PubMed PMID: 25452775. Pubmed Central PMCID: 4247306.

[23] Prins NH, Van Der Grijn A, Lefebvre RA, Akkermans LM, Schuurkes JA. 5-HT(4) receptors mediating enhancement of contractility in canine stomach; an in vitro and in vivo study. British journal of pharmacology. 2001 Apr;132(8):1941-7. PubMed PMID: 11309267. Pubmed Central PMCID: 1572724.

[24] Janssen P, Prins NH, Meulemans AL, Lefebvre RA. Pharmacological characterization of the 5-HT receptors mediating contraction and relaxation of canine isolated proximal stomach smooth muscle. British journal of pharmacology. 2002 May;136(2):321-9. PubMed PMID: 12010782. Pubmed Central PMCID: 1573351.

[25] Janssen P, Prins NH, Moreaux B, Meulemans AL, Lefebvre RA. In vivo characterization of 5-HT1A receptor-mediated gastric relaxation in conscious dogs. British journal of pharmacology. 2003 Nov;140(5):913-20. PubMed PMID: 14517177. Pubmed Central PMCID: 1574099.

[26] Spechler SJ, Sharma P, Souza RF, Inadomi JM, Shaheen NJ, American Gastroenterological A. American Gastroenterological Association technical review on the management of Barrett's esophagus. Gastroenterology. 2011 Mar;140(3):e18-52; quiz e13. PubMed PMID: 21376939. Pubmed Central PMCID: 3258495. 
[27] Fitzgerald RC, Di Pietro M, Ragunath K, Ang Y, Kang JY, Watson P, et al. British Society of Gastroenterology guidelines on the diagnosis and management of Barrett's oesophagus. Gut. 2014 Jan;63(1):7-42. PubMed PMID: 24165758.

[28] Rindi G, Bishop AE, Daly MJ, Isaacs P, Lee FI, Polak JM. A mixed pattern of endocrine cells in metaplastic Barrett's oesophagus. Evidence that the epithelium derives from a pluripotential stem cell. Histochemistry. 1987;87(4):377-83. PubMed PMID: 2447038.

[29] Buchan AM, Grant S, Freeman HJ. Regulatory peptides in Barrett's oesophagus. The journal of pathology. 1985 Jul;146(3):227-34. PubMed PMID: 2863340. 
